\title{
Anaesthetists' role in neonatal resuscitation and care of the newborn
}

Gerard W. Ostheimer MD

Birth is a time of physiological stress and change for the fetus. Usually, the asphyxial stress of birth is mild to moderate, and the newborn is able to compensate for it. When the neonate's compensatory ability is decreased or the asphyxial stress is excessive, resuscitative intervention is necessary to assist in the conversion from fetal to neonatal physiology.

Standard IV of the ASA "Guidelines for Conduction Anesthesia in Obstetrics" states: Qualified personnel, other than the anesthetist attending the mother, should be immediately available to assume responsibility for resuscitation of the depressed newborn. (The primary responsibility of the anaesthetist is to provide care to the mother. If the anaesthetist is also requested to provide brief assistance in the care of the newborn, the benefit to the child must be compared to the risk of temporarily leaving the mother.)

The "Guidelines for perinatal care"1 state: The first minutes of life may determine the quality of that life. The need for a prompt, organized, and skilled response to emergencies in this period requires institutions that provide maternal-fetal care to have written policies delineating responsibility to immediate newborn care, resuscitation, selection and maintenance of necessary equipment, and training of personnel in proper techniques. The obstetrician is responsible for providing immediate postdelivery care of the newborn and for ascertaining that the newborn adaptations to extrauterine life are proceeding normally. The hospital rules and regulations should include protocols for the transfer of medical care of the neonate in both routine and emergency circumstances. Routine care of the healthy newborn may be delegated to appropriately trained nurses.

Recognition and immediate resuscitation of the distressed neonate require an organized plan of action and the immediate availability of qualified personnel and equipment. At least one person skilled in initiating resuscitation should be present at every delivery. Responsibility for identification and resuscitation of a distressed neonate should be assigned to a qualified individual, who may be a physician or an appropriately trained nursemidwife, labour and delivery nurse, nurse-anaesthetist, nursery nurse, or respiratory therapist. The provision of services and equipment for resuscitation should be planned jointly by the directors of the departments of obstetrics, anaesthesia, and paediatrics, with the approval of the medical staff. A physician should be designated to assume primary responsibility for initiating, supervising, and reviewing the plan for management of depressed neonates in the delivery room.

Gibbs et al., $1986,{ }^{2}$ found that in small units in the USA, with less than 500 deliveries per year, personnel other than an anaesthetist, nurse anaesthetist, paediatrician or obstetrician perform newborn resuscitation after vaginal delivery almost $50 \%$ of the time, and, for Caesarean delivery, $25 \%$ of the time.

\section{Cardiovascular physiology (fetus to newborn)}

The fetal circulation operates in series. ${ }^{3,4}$ In the fetus, oxygenated blood returns from the placenta via the umbilical vein, largely bypassing the liver through the ductus venosus. Due to a streaming effect this blood is preferentially shunted from the right atrium through the foramen ovale to the left atrium and via the left ventricle into the systemic circulation. This streaming of ductus venosus blood to the left side of the circulation enhances the oxygen content of the blood perfusing the organs of highest oxygen consumption - the heart and the brain.

Desaturated blood returns from the upper part of the body via the superior vena cava and streams into the right ventricle. Right ventricular output encounters high pulmonary vascular resistance due to arteriolar vasoconstriction. About $90 \%$ of this right-sided output passes through the ductus arteriosus and enters the aorta distal to the branches of the aortic arch; thus less well-oxygenated blood perfuses the lower body which has a lower oxygen consumption.

At birth, two primary events initiate the conversion from fetal to adult circulatory patterns. ${ }^{5}$ First, cessation of umbilical artery flow (by clamping the cord or ex-

From the Department of Anesthesiology, Brigham and Women's Hospital, 75 Francis St., Boston, Mass. 
posing the cord to air) increases systemic vascular resistance and aortic pressure, and the clamping of the umbilical vein decreases venous return and right atrial pressure. This effects a decrease in the right-to-left shunts both at the foramen ovale from the right atrium to the left and at the ductus arteriosus from the pulmonary artery to the aorta. Second, the expansion of the lungs at birth stimulates pulmonary vasodilatation, with resulting decreases in pulmonary vascular resistance and pulmonary arterial pressure which helps to reduce further the right-to-left flow through the patent ductus arteriosus. Pulmonary blood flow increases, oxygenation improves, and left atrial pressure rises, further decreasing the shunt across the foramen ovale.

The hallmarks of conversion to adult circulation are a rise in systemic arterial pressure, accomplished mainly by cord clamping, and a rise in pulmonary blood flow, accomplished by filling the lungs with air. Therefore, the major effort of resuscitation is usually to assist the neonate with the initiation of ventilation. More severely depressed neonates may require additional forms of intervention.

The adult circulatory pattern is established rapidly in the normal, healthy neonate. However, for the first two weeks of life (longer in the premature), the circulation can revert to the fetal pattern (persistent fetal circulation or primary pulmonary hypertension) when the neonate is subjected to certain stresses such as hypoxaemia, acidosis, hypercarbia, hypovolaemia, shock and hypothermia. $^{s}$

\section{Respiratory system}

The fetal lung develops by a budding process from the foregut at approximately 24 days of gestation. By $20 \mathrm{wk}$, the airways are lined with epithelium and pulmonary capillaries are developing in the mesenchyme. By 26 to 28 $\mathrm{wk}$, the capillaries are close to the developing airways so that oxygen and carbon dioxide exchange could occur making extra-uterine life possible. Surfactant-like material is present in the airway epithelium between 22 to $24 \mathrm{wk}$ but is not present on the alveolar surface until 26 to $28 \mathrm{wk}$. Steroids administered to the mother facilitate the development of the epithelial cells lining the alveoli and the production of surfactant. The onset of fetal breathing is stimulated by stress (usually hypoxia) and amniotic fluid can be drawn into the lung as can be demonstrated by meconium aspiration in the stillborn. ${ }^{6,7}$

Normal newborns will begin spontaneous respirations within 30 to $60 \mathrm{sec}$. Stimuli to breathe include: rebound of the thoracic cage after vaginal birth, mild to moderate hypoxia, cord clamping, cold environment and tactile stimulation. (Note: only gentle stimulation is needed. Vigorous spanking, cold and hot water baths, and other ex-
TABLE I Normal neonatal blood pressures

\begin{tabular}{lllll}
\hline Birthweight (kg) & $<1.0$ & $1.0-2.0$ & $2.0-3.0$ & $>3.0$ \\
Pressure (mmHg) & & & & \\
- Systolic & $40-60$ & $50-65$ & $50-70$ & $50-80$ \\
- Diastolic & $15-35$ & $20-40$ & $25-40$ & $30-50$ \\
\hline
\end{tabular}

cessive stimulation have no therapeutic value and may be harmful.) The volume of the first breath is from 20-75 $\mathrm{ml}$. Subsequent tidal volume is $15-20 \mathrm{ml}$. When rhythmic breathing is established and the lungs are fully expanded, the normal respiratory rate is $30-40 \mathrm{bpm}$. In the first few hours of life, during the resorption of residual lung fluid, respiratory rates may be as high as $60-90 \mathrm{bpm}$. Central cyanosis should clear by five minutes after birth. Some peripheral cyanosis may persist due to peripheral vasoconstriction. During vaginal delivery, the baby's chest is compressed with a pressure of $30-250 \mathrm{~cm} \mathrm{H}_{2} \mathrm{O} .{ }^{8}$ This "squeeze" expresses much of the fluid from the lungs, but the lungs remain collapsed and are not aerated. In order to expand the lungs against the collapsing forces of alveolar tension and elastic pulmonary recoil, the neonate exerts 40 to $80 \mathrm{~cm} \mathrm{H}_{2} \mathrm{O}$ negative pressure. The resuscitator may, therefore, need to use higher than normal pressures when assisting with the initiation of ventilation, so long as the potential for pneumothorax is kept in mind. The newborn will respond to a large rapid inflation of its lungs with a sharp inspiration of its own - Head's paradoxical reflex.

\section{Cardiovascular system}

The heart rate may vary from $100-200 \mathrm{bpm}$ during the first $30 \mathrm{~min}$ of life, but should stabilize at $120 \pm 50$ bpm thereafter. Normal blood pressure varies with birthweight, as shown in Table I." A systolic pressure less than $50 \mathrm{mmHg}$ in a term newborn is abnormally low and should be treated promptly with intravascular volume expansion. Normal intravascular volume is 85 to 100 $\mathrm{mg} \cdot \mathrm{kg}^{-1}$ in the newborn.

\section{Thermoregulation}

Man is homeothermic - that is, he increases his heat production when exposed to a cold environment to maintain body temperature. Pokilotherms, such as reptiles, cannot increase their heart production and their body temperature drifts to that of the environment. There are two methods of increasing heat production: a physical method of muscle contraction (shivering) used by children and a chemical method used by neonates called nonshivering thermogenesis. When the newborn is cold stressed, he/she increases his/her oxygen consumption and metabolic activity. Large amounts of norepinephrine 
are released in contrast to epinephrine in adults which activates an adipose tissue lipase to break down brown fat (so called because of its rich vascular supply) to form triglycerides and non-esterified fatty acids (NEFA). The NEFA may pass out of the cell, are oxidized to carbon dioxide and water in the cell which is an exothermic (heat producing) reaction or are re-esterified with glycerol to form triglycerides. Adipose tissue is not able to phosphorylate the glycerol derived from the triglycerides; therefore, re-esterification via the coenzyme A-NEFA complex requires a supply of $\div$-glycerol phosphate derived from glucose that comes from outside the cell. Resynthesis of triglycerides is also an exothermic reaction because of the utilization of ATP in the formation of the coenzyme A-NEFA complex.

Non-shivering thermogenesis occurs mainly in the brown fat of the neonate which is found at the following sites: an interscapular mass - the "hibernating gland," muscles and blood vessels entering the thoracic inlet and abdominal viscera - especially around the kidneys and adrenal glands. The venous drainage from the interscapular adipose tissue joins the drainage from the muscles of the back to form the external vertebral plexus which drains to the rich venous plexus around the spinal cord that in turn enters the jugular or azygous veins depending on the level - thus supplying heat to the spinal cord and the heart.

We must strive to maintain a neutral thermal environment $\left(32-34^{\circ} \mathrm{C}\right.$ for newborns) at which metabolism (as reflected by oxygen consumption) is minimal yet sufficient to maintain body temperature. Minimal oxygen consumption occurs when the gradient between skin and the environmental temperature is less than $1.5^{\circ} \mathrm{C}$.

The infant, born into the cold environment of the delivery room, suffers an enormous heat loss - initially, by evaporation since the neonate is wet from amniotic fluid and has a large surface area. Once the skin is dried, heat loss is mainly by radiation. Dahm and James ${ }^{12}$ investigated heat loss in the $30 \mathrm{~min}$ after delivery and found that wet infants exposed to room air lost nearly five times more heat than those who were dried and warmed.

In vigorous infants, promptly drying the skin and wrapping the baby in a warm blanket is almost as effective in decreasing heat loss as placing the baby under a radiant heater. However, in depressed or immature infants who may be more asphyxiated or have reduced energy stores, an overhead radiant heater maintains body temperature while allowing access to the patient during resuscitation.

\section{Routine delivery room care of the normal neonate}

The following measures are all that is necessary in 85 to $90 \%$ of deliveries:
1 Aspirate the mouth and nose by bulb syringe.

2 Dry the skin and maintain normal newborn temperature.

3 Routine identification procedures.

4 Ophthalmic prophylaxis (required by law in most states of the USA).

In the remainder, neonatal depression has occurred and further measures will be necessary.

\section{Principles of newborn resuscitation}

The principles of newborn resuscitation follow the same principles as adult resuscitation:

1 Airway management.

2 Breathing.

3 Circulation or adequate cardiac output to maintain cerebral oxygenation.

After birth of the baby's head, the oropharynx is suctioned with a bulb syringe before the baby's first breath and while the chest is still compressed in the vaginal canal (vaginal squeeze) to prevent aspiration of mucus and debris into the trachea with the onset of respiration. The baby is then delivered; the umbilical cord is clamped and cut and the newborn is transferred by the obstetrician to a warmed bassinet which has been placed in a $20^{\circ}-30^{\circ}$ head down position to facilitate the gravity drainage of liquid material into the oropharynx. A slight lateral tilt of the newborn concentrates the pooling of secretions into one corner of the oropharynx.

Management of the airway is accomplished by gentle suction with a bulb syringe if possible - not a plastic or rubber suction catheter. Corero and Hon ${ }^{13}$ investigated the effect of nasopharyngeal or oropharyngeal stimulation on heart rate and respiration. In 41 infants who received repeated nasopharyngeal suction with a bulb syringe, no decreases in heart rate or respiration were noted. However, in 46 neonates who were suctioned blindly with a catheter through the nose or mouth, seven developed severe cardiac arrhythmias and five became apnoeic. These undesirable responses resulted from stimulation of afferent vagal fibres in the posterior pharynx of already highly vagotonic newborns.

Gentle slapping of the feet is all the stimulation needed for the healthy newborn. Spanking, cold water showers, jackknifing, "milking" the trachea, dilation of the anal sphincter, alternating hot and cold baths, rocking beds and excessive rubbing of the back are condemned as having no therapeutic value and are potentially harmful.

\section{Resuscitation equipment}

Every delivery area should have the following equipment readily available for the resuscitation of the newborn:

1 a source of $100 \%$ oxygen;

2 a bag and mask for intermittent positive pressure ven- 
TABLE II Apgar scoring system

\begin{tabular}{|c|c|c|c|c|c|}
\hline Evaluation & Sign & Stimulus & 0 & 1 & 2 \\
\hline Appearance & Colour & Visual assessment & Blue, pale & Body pink, extremities blue & Completely pink \\
\hline Pulse & Heart rate & Count cord pulse or auscultate heart & Absent & $<100 \mathrm{bpm}$ & $>100 \mathrm{bpm}$ \\
\hline Grimace & Reflex irritability & Flick sole of foot & No response & Some motion & Cry \\
\hline Activity & Muscle tone & Manipulate extremity & Limp/flaccid & Some flexion of extremities & Well-flexed \\
\hline Respiration & Respiratory effort & Visual assessment & Absent & Slow, irregular hypoventilation & Good strong cry \\
\hline
\end{tabular}

tilation (IPPV). A flow-through system which does not require positive pressure for oxygen delivery should be used since most neonates will not need IPPV, just oxygen therapy. However, if IPPV is necessary, it can be administered with a cushioned face mask and manual ventilation;

3 a bulb syringe for suctioning the nose and oropharynx;

4 a deLee suction catheter with mucus trap for aspiration of mucus, meconium, blood and other secretions or stomach contents;

5 laryngoscopes with size 0 and 1 straight blades;

6 endotracheal tubes (Cole orotracheal tubes or straight endotracheal tubes with stylets in place in sizes $1.5 \mathrm{~mm}$, $2.0 \mathrm{~mm}, 2.5 \mathrm{~mm}$. $3.0 \mathrm{~mm}$, and $3.5 \mathrm{~mm}$ ). The Cole tubes are more rigid and do not require a stylet. If the neonate requires long-term ventilation, the oral tube should be changed to a straight nasotracheal tube when the infant's condition is stable;

7 oral airways, size 00 and 0 , are rarely needed but should be available;

8 a radiant heater with servomechanisms.

A neonatal "code cart" also should be available and should contain equipment for vascular access and blood sampling, intravenous infusions, drugs commonly employed in resuscitation, and charts showing typical doses and dilutions.

With the increasing concern about body fluids contaminated with hepatitis or human immunodeficiency virus (HIV), personnel participating in newborn resuscitation are using one of several devices that allows aspiration of fluids from the mouth, trachea and stomach of the newborn by vacuum suction $\left(<80 \mathrm{~cm} \mathrm{H}_{2} \mathrm{O}\right)$. This approach should eliminate the possibility of inhaling contaminants through a mask or gauze covering while aspirating via the endotracheal tube or deLee suction apparatus.

\section{Evaluation and treatment of the depressed neonate}

\section{Apgar scoring}

It is easy to recognize the vigorous, healthy, normal neonate and the severely depressed neonate needing immediate cardiopulmonary resuscitation. Between these two extremes lie varying degrees of neonatal depression. While the Apgar scoring system (Table II) was not meant to be used as a guide to resuscitators, it has proved useful as a means of quantifying the degree of depression. The one-minute score (Apgar, 1953) ${ }^{14}$ will be used here as a guide to the intervention required. However, resuscitation should not be delayed awaiting the one-minute Apgar score. A follow-up score is determined at five minutes of life and will indicate the progress of the newborn and the resuscitation. Additionally, 10, 15 and $20 \mathrm{~min}$ scores may be assigned to document the response of the neonate to the resuscitative efforts.

Vigorous, crying infant (Apgar score 7-10)

No therapy is necessary beyond the routine measures mentioned above.

\section{Moderate depression (Apgar Score 4-6)}

1 Administer $100 \%$ oxygen by bag and mask.

2 Stimulate by slapping the feet or by drying the skin with a soft cloth towel or blanket.

3. If the heart rate is below 100 and/or respirations are inadequate, begin intermittent positive pressure ventilation (IPPV) by bag and mask and continue it as long as necessary.

4 Monitor the heart rate and spontaneous respiratory effects. If these deteriorate or fail to improve, treat as a severely depressed neonate.

\section{Severe depression (Apgar score 0-3)}

1 Ventilate with $100 \%$ oxygen by bag and mask as soon as possible;

2 If there is no response (increased heart rate, improved respiratory effort) within a few minutes, perform larygoscopy, suction the oropharynx and/or trachea, and intubate the trachea to facilitate ventilation.

3 Initiate closed chest cardiac massage (CCCM) if the heart rate remains below $100 \mathrm{bpm}$. Place both thumbs over the mid- to lower third of the sternum and the fingers behind the chest. ${ }^{15,16}$ Compress the chest at a rate of 120 beats min $^{-1}$, depressing the sternum twothirds of the way to the vertebral column.

4 Monitor the adequacy of cardiopulmonary resuscitation. With proper intubation and ventilation the chest 
should expand and breath sounds should be heard in both axillae. Auscultate over the abdomen to rule out oesophageal intubation. If ventilation and/or intubation are difficult, repositioning of the head may be necessary. Because of the relatively large head of the neonate, as well as the oedema fluid (caput) that collects over the occiput during labour, the neck may be flexed enough to compress the trachea when the baby is supine. Place a small roll under the baby's shoulders to alleviate this problem by extending the neck. However, excessive hyperextension may also compress the soft trachea of the newborn.

5 Gastric aspiration should not be done in the first few minutes of life in order to avoid causing any arrhythmias from nasopharyngeal or oropharyngeal stimulation - unless there is massive gastric dilation secondary to IPPV with the bag and mask or a tracheoesophageal fistula is suspected. Cordero and Hon ${ }^{13}$ suggest that after five minutes, the neonate has become physiologically more stable and will tolerate passage of a nasogastric tube.

\section{Continued moderate to severe depression}

The newborn that fails to respond to adequate ventilation with oxygen and circulatory support with CCCM will require further therapy.

Drugs commonly used in neonatal resuscitation are administered through an umbilical artery or vein catheter, although epinephrine can be given intratracheally if vascular access has not yet been established. A \#5 or \#8 French gauge catheter can be threaded into the umbilical artery, although intense vasoconstriction of the artery may necessitate use of the umbilical vein in the immediate resuscitative period. In the latter case, the catheter should be threaded no more than $2 \mathrm{~cm}$ into the vein to avoid cannulation of a major hepatic vessel.

\section{Drugs used in pharmacologic resuscitation}

\section{Epinephrine (adrenaline) $\left(0.05 \mathrm{mg} \cdot \mathrm{kg}^{-1}\right)$}

The hypotensive, bradycardic infant who is still acidotic may require this high dose of epinephrine for cardiac stimulation. In the non-acidotic infant, the usual dose of epinephrine is $0.01 \mathrm{mg} \cdot \mathrm{kg}^{-1}$.

\section{Sodium bicarbonate $\left(2 \mathrm{mmol} \cdot \mathrm{kg}^{-1}\right)$}

The newborn suffering from severe birth asphyxia and not responding well to oxygen and ventilatory support probably has a respiratory and metabolic acidosis. This initial dose of sodium bicarbonate will improve the acidosis, and further doses should be administered only as indicated by the infant's $\mathrm{pH}$. A sample of blood (arterial or venous) should be drawn for blood gas analysis upon insertion of the umbilical artery or vein catheter. Ventilation must be adequate to reverse the respiratory component of the acidosis.

Bicarbonate therapy has several potential complications. ${ }^{17-20}$ It is a hyperosmolar solution, and its rapid administration in the acidotic and hypoxic newborn can lead to profound vasodilatation and hypotension due to skeletal muscle vasodilatation and venous pooling. Because of its lower osmolarity, a $0.22 \mathrm{mmol} \cdot \mathrm{ml}^{-1}$ solution is preferred to the $0.45 \mathrm{mmol} \cdot \mathrm{ml}^{-1}$ solution. It should be given in an intravenous infusion (5-10\% dextrose or $0.45 \%$ saline) so that the solution can serve as a diluent to decrease the bolus effect of the sodium bicarbonate. Excessive sodium bicarbonate therapy has been shown to cause hypernatraemia which has been implicated in intracranial haemorrhage in the sick neonate. ${ }^{20}$ However, appropriate doses, guided by the infant's $\mathrm{pH}$, appear to be safe in this regard.

Naloxone $\left(0.1 \mathrm{mg} \cdot \mathrm{kg}^{-1}\right.$ iv or $0.2 \mathrm{mg} \cdot \mathrm{kg}^{-1}$ im)

Naloxone is used to reverse narcotic-related depression only. If the mother has received narcotics, the neonate may require naloxone. If this is so, the neonate should be observed for at least four hours after naloxone administration for evidence of recurrence of narcotic depression.

If the mother has received general anaesthesia for delivery, the anaesthetic can have a depressant effect on the newborn. Usually all the baby needs is oxygen, stimulation, and time to "wake up." Naloxone is not necessary in this setting, unless the mother has received narcotics as a part of the anaesthetic.

Dextrose $\left(2 \mathrm{~g} \cdot \mathrm{kg}^{-1} i v\right.$ push, then $\left.5-8 \mathrm{mg} \cdot \mathrm{kg}^{-1} \cdot \min ^{-1}\right)$ Severely asphyxiated infants are often hypoglycaemic due to their increased catecholamine levels with initial elevation of glucose and stimulation of insulin secretion in the presence of decreased glycogen reserves and immature gluconeogenic pathways. ${ }^{5}$ Newborns born to diabetic mothers are at risk for hypoglycaemia because of prolonged exposure to maternal hypoglycaemia with fetal islet cell hyperplasia and elevated insulin secretion. Those neonates who are small for gestational age or have suffered from uteroplacental insufficiency also may develop hypoglycaemia because of depleted glycogen stores. Hypoglycaemia in these infants may be of later onset and they will require longer monitoring of blood glucose levels.

Other drugs may be needed in prolonged resuscitation. The indications for and methods of their use is not discussed here in the context of the acute resuscitative effort, and their use is the perogative of the attending pediatrician. 


\section{Specific neonatal problems}

\section{Meconium staining}

Passage of meconium by the fetus is thought to occur in response to hypoxic stress in the ante- or peripartum period. ${ }^{21}$ Meconium staining is present in $8-15 \%$ of all pregnancies, with a higher incidence occurring in the post-term pregnancy. Over half of infants born through meconium-stained fluid will have meconium in their tracheas, and if left untreated many will develop meconium aspiration syndrome. ${ }^{22-24}$ Since the treatment for meconium aspiration syndrome is only supportive and symptomatic, efforts have been concentrated on the prevention of the syndrome through thorough, aggressive airway suctioning at birth. ${ }^{23-25}$ When thick particulate meconium is present in the amniotic fluid, the following therapy should be initiated. Immediately after the delivery of the infant's head, while the chest is still in the birth canal or uterus (at Caesarean delivery) the oropharynx and nasopahrynx should be suctioned thoroughly by the obstetrician, using a bulb syringe or a deLee appartus. Immediately after delivery and, if possible, before the infant has taken its first breath, laryngoscopy and tracheal suctioning should be performed by the most experienced person present, regardless of the presence or absence of meconium in the oropharynx and nasopharynx since the obstetrician may have already completely cleared the upper airways of meconium. Tracheal suctioning should be repeated until no further meconium can be aspirated. An assistant should monitor the baby's heart rate during suctioning, since pharyngeal stimulation can cause bradycardia and other arrhythmias through vagal reflexes. ${ }^{13}$ If the heart rate slows substantially, oxygen by mask or by clean tracheal tube should be administered by IPPV. Infants that have aspirated meconium should receive chest physiotherapy and postural drainage with suctioning, and should be monitored closely for the occurrence of respiratory distress. This sequence of immediate, thorough pharyngeal and tracheal suctioning has been found to be safe, and its implementation has greatly reduced the incidence and severity of meconium aspiration syndrome and its subsequent morbidity and mortality. ${ }^{23,24}$

\section{Neonatal shock}

Serious hypovolaemia with secondary hypoperfusion and tissue hypoxia can occur as a result of numerous factors. Sequestration of blood in the placenta because of elevation of the infant above the mother at the time of cord clamping, prolapsed umbilical cord, abruptio placenta, placenta praevia, and rupture of the umbilical cord can significantly decrease the newborn's circulating blood volume. Low birthweight infants may have decreased total protein concentrations, with a resultant shift of fluid out of the intravascular space because of low intravascular oncotic pressure. Also, maternal sepsis transmitted to the fetus may present as neonatal shock.

A decreasing blood pressure, tachycardia, pallor, decreased urine output, decreasing haematocrit or metabolic acidaemia all indicate that volume expansion may be needed. One therapy is $20 \mathrm{ml} \cdot \mathrm{kg}^{-1}$ of fresh, uncontaminated heparinized fetal whole blood obtained from the placenta, which may be difficult to obtain. ${ }^{26,27}$ If this is unavailable, fresh whole adult blood or, in most hospitals, packed red cells and fresh frozen plasma in the same quantity may be used. Five percent albumin, 1 $\mathrm{g} \cdot \mathrm{kg}^{-1}$, can also serve as a volume expander. Finally, if no blood products are available, lactated Ringer's solution or $0.45 \%$ normal saline may be used. The newborn's blood pressure, pulse, respiration and temperature should be monitored carefully to detect any deterioration before such a change becomes a crisis.

Constant monitoring of the hypotensive neonate is vital to proper management. Measurement of the infant's blood pressure should become a routine part of the physiological evaluation at birth if a problem exists and all infants should have a screening blood pressure measured on admission to the nursery. The newborn is "recovering" from the asphyxia of delivery and should have the same evaluation as a patient "recovering" from anaesthesia and surgery.

\section{Summary}

The simple mnemonic ABCDE summarizes the five key principles of neonatal resuscitation:

1 Airway.

2 Breathing.

3 Circulation.

4 Drugs.

5 Evaluation. of concurrent and causative problems and maintenance of a neutral thermal environment.

\section{References}

1 Frigoletto FD, Little GA. Guidelines for Perinatal Care (2nd Ed). American Academy of Pediatrics and the American College of Obstetricians and Gynecologists, 1988.

2 Gibbs CP, Krischer J, Peckham BM, Sharp H, Kirschbaum TH. Obstetric anesthesia: a national survey. Anesthesiology 1986; 65: 298-306.

3 Behrman RE, Lees MH, Peterson EN, De Lannoy CW, Seeds $A E$. Distribution of the circulation in the normal and asphyxiated fetal primate. Am J Obstet Gynecol 1970; 108: 956-69.

4 Rudolph AM, Heymann MA. Fetal and neonatal circulation and respiration. Annu Rev Physiol 1974; 36: 187-207.

5 Bowen $F W$. Resuscitation and stabilization of the neonate. In: Bolognese $\mathrm{RJ}$ (Ed.). Perinatal Medicine: Management 
of the High Risk Fetus and Neonate, Baltimore: Williams \& Wilkins, 1982; 445-53.

6 Brown $B L$, Gleicher $N$. Intrauterine meconium aspiration. Obstet Gynecol 1981; 57: 26-9.

7 Turbeville DF, McCaffress $M A$, Block $M F$, Krous $H F$. In utero distal pulmonary meconium aspiration. South Med J 1979; 72: 535-6.

8 Karlberg $P$. the adaptive changes in the immediate postnatal period, with particular reference to respiration. J Pediatrics 1960; 56: 585-604.

9 Vyas H, Milner AD, Hopkin IE. Intrathoracic pressure and volume changes during the spontaneous onset of respiration in babies bom by cesarean section and by vaginal delivery. J Pediatr 1981; 99: 787-91.

10 Milner $A D$, Vyas $H$. Lung expansion at birth. J Pediatr 1982; 101: 879-86.

11 Versmold HT, Kitterman JA, Phibbs RH, Gregory GA, Tooley $W H$. Aortic blood pressure during the first 12 hours of life in infants with birth weight 610 to 4420 grams. Pediatrics 1981; 67: 607-13.

$12 \mathrm{Dahm} L S$, James $L S$. Newborn temperature and calculated heat loss in the delivery room. Pediatrics 1972; 49 : 504-13.

13 Cordero L, Hon EH. Neonatal bradycardia following nasopharyngeal stimulation. J Pediatr 1971; 78: 441-7.

14 Apgar V. A proposal for a new method of evaluation of the newborn infant. Anesth Analg 1953; 32: 260-7.

15 Todres ID, Rogers $M C$. Methods of external cardiac massage in the newborn infant. J Pediatr 1975; 86: 781-2.

16 Finholt DA, Kettrick RG, Wagner HR, Swedlow $D B$. The heart is under the lower third of the sternum. Implications for external cardiac massage. Am J Dis Child 1986; 140 646-9.

17 Simmons MA, Adcock EW 3rd, Bard H, Battaglia FC. Hypernatremia and intracranial hemorrhage in neonates. $N$ Engl J Med 1974; 29I: 6-10.

18 Volpe $J$. Neonatal intracranial hemorrhage - iatrogenic etiology? (editorial) N Engl J Med 1974; 291: 43-5.

19 Cote CJ, Greenhow DE, Marshall BE. The hypotensive response to rapid intravenous administration of hypertonic solutions in man and in the rabbit. Anesthesiology 1979; 50: $30-5$.

20 Wheeler AS, Sadri S, Gutsche BB, DeVore JS, DavidMian $Z$. Intracranial hemorrhage following intravenous administration of sodium bicarbonate or saline solution in the newborn lamb asphyxiated in utero. Anesthesiology 1979; 51: 517-21.

21 Walker J. Fetal anoxia. J Obstet Gynecol Br Common 1953; 60: 162-80.

22 Gregory GA, Gooding CA, Phibbs RH, et al. Meconium aspiration in infants: A prospective study. J Pediatr 1984; 85: 848-52.

23 Ting $P$, Brady $J P$. Tracheal suction in meconium aspira- tion. Am J Obstet Gynecol 1975; 122: 767-71.

24 Carson BS, Losey RW, Bowes WA Jr. Simmons MA. Combined obstetric and pediatric approach to prevent meconium aspiration syndrome. Am J Obstet Gynecol 1976; 126: $712-5$.

25 Frantz ID, Wang NS, Thach BT. Experimental meconium aspiration: effects of glucocorticoid treatment. J Pediatr 1975; 86: 438-41.

26 Paxson CL Jr. Collection and use of autologous fetal blood. Am J Obstet Gynecol 1979; 134: 708-10.

27 Golden SM, O'Brien WF, Metz SA. Anticoagulation of autologous cord blood for neonatal resuscitation. Am J Obstet Gynecol 1982; 144: 103-4. 


\section{Le rôle de l'anesthésiste dans la réanimation et les soins du nouveau-né}

La naissance constitue une période de stress et de changements physiologiques pour le foetus. Ordinairement le stress de l'asphyxie natale est léger ou modéré et le nouveau-né y fait face sans difficulté. Quand il manque de résistance ou quand le stress devient excessif, la conversion de la physiologie foetale à la physiologie néonatale nécessite la réanimation.

Le standard IV des recommandations de l'ASA sur l'anesthésie régionale obstétricale oblige à la présence immédiate d'un personnel compétent pour prendre en charge la réanimation du nouveau-né. (La responsabilité primaire de l'anesthésiste est de donner des soins à la mère. $\mathrm{Si}$ on lui demande de donner assistance au nouveau-né, il doit soupeser le bénéfice de la réanimation du bébé contre le risque causé par l'abandon temporaire de la mère).

Les recommandations sur les soins périnataux ${ }^{1}$ rappellent que les premières minutes d'une vie sont déterminantes pour la qualité de cette vie. La formation d'un personnel compétent, l'accès et l'entretien d'un matériel de réanimation approprié et de qualité font partie des responsabilités des institutions qui dispensent des soins foetaux-maternels. L'obstétricien demeure néanmoins responsable des soins immédiats au nouveau-né et de son adaptation à la vie extra-utérine. Les règlements hospitaliers doivent incorporer des protocoles pour le transfert médical des soins du nouveau-né dans tous le cas. Les soins usuels du nouveau-né normal peuvent être délégués à des infirmières compétentes.

Le diagnostic et le traitement immédiat du nouveauné en détresse nécessite un plan d'organisation et la disponibilité immédiate d'équipement et de personnel. Au moins une personne compétente pour débuter la réanimation doit être sur place à chaque naissance. La responsabilité de porter secours au nouveau-né en détresse doit être assignée à une personne qualifiée que ce soit un médecin ou une sage-femme, une infirmière de la salle travail ou d'accouchement, une infirmière anesthésiste, une infirmière néonatalogiste ou un inhalothérapeute. L'achat de l'équipement et l'organisation des services de réanimation doivent être planifiés conjointement par les directeurs des départments d'obstétrique, d'anesthésie et de pédiatrie et approuvés par les conseils de médecins. Un médecin doit être désigné spécifiquement pour as- sumer la responsabilité à la salle d'accouchement de l'initiation, de la supervision et de la révision du plan de traitement des nouveaux-nés à risque.

Gibbs $e t$ al. en $1986^{2}$ ont constaté que dans les petites unités obstétricales américaines de moins de 500 accouchements par année, des personnels autres que l'anesthésiste, l'infirmière anesthésiste, le pédiatre et l'obstétricien exécutaient les manoeuvres de réanimation dans $50 \%$ des accouchements vaginaux et dans $25 \%$ des césariennes.

\section{Physiologie cardiovasculaire (de la vie foetale à la vie néo-natale)}

La circulation foetale est structurée en série. ${ }^{3,4} \mathrm{Chez}$ le foetus, le sang oxygéné retourne du placenta par la veine ombilicale, en court-circuitant le foie par le ductus venosus. Ce sang est dévié. de façon préférentielle à l'oreillette droite vers l'oreillette gauche via le foramen ovale et par le ventricule gauche vers la circulation systémique. Cette répartition du sang du ductus venosus vers la circulation gauche augmente le contenu en oxygène du sang qui perfuse les organes qui consomment le plus d'oxygène, le coeur et le cerveau.

Le sang désaturé retourne de la partie supérieure de l'organisme par la veine cave supérieure et parvient au ventricule droit. Le débit ventriculaire droit rencontre une résistance vasculaire pulmonaire élevée par vasoconstriction artériolaire. Environ $90 \%$ du débit du coeur droit passe à travers le canal artériel et pénètre dans l'aorte distalement aux branches de l'arche aortique; ainsi un sang moins oxygéné perfuse le partie inférieure du corps qui consomme le moins d'oxygène.

A la naissance, deux évènements principaux initient la conversion de la circulation foetale au modèle adulte. ${ }^{5}$ D'abord, l'arrêt du courant sanguin ombilical (par clampage ou exposition à l'air) augmente la résistance vasculaire systémique et la pression aortique, alors que le clampage du cordon diminue le retour veineux et la pression auriculaire droite. Ceci diminue le shunting droitgauche par le foramen ovale, de l'oreillette droite à l'oreillette gauche; par le ductus arteriosus, de l'artère pulmonaire à l'aorte. Ensuite, l'expansion des poumons entraîne la vasodilatation pulmonaire, ce qui diminue la résistance vasculaire et la pression artérielle pulmonaire: par conséquent, le débit droit-gauche du canal arté- 
riel baisse encore plus. Le débit pulmonaire augmente, l'oxygénation s'améliore et la pression auriculaire gauche s'élève, avec une diminution subséquente du shunt par le foramen ovale.

La conversion à la circulation adulte est marquée par une élévation de la pression artérielle systémique, causée par le clámpage ombilical et une augmentation du débit sanguin pulmonaire, causée par le remplissage pulmonaire par l'air. De là, l'effort majeur du réanimateur consistera à aider à linitiation de la respiration. Les nouveaux-né plus déprimés peuvent avoir besoin d'interventions supplémentaires.

Le modèle de circulation adulte s'établit rapidement chez le nouveau-né normal en bonne santé. Cependant, pendant les deux premières semaines de vie (encore plus tardivement chez le prématuré), la circulation peut retourner au modèle foetal (circulation foetale persistante ou hypertension pulmonaire primaire) sous l'effet de stress comme l'hypoxémie, l'acidose, l'hypercarbie, l'hypovolémie, le shock et l'hypothermie. ${ }^{5}$

\section{Système respiratoire}

Le poumon foetal se développe par bourgeonnement de l'intestin antérieur vers le 24ième jour de la gestation. A la 20ième semaine, les voies respiratoires sont recouvertes d'épithélium et des capillaires prolifèrent dans le mésenchyme. De la 26ième à la 28ième semaine, les capillaires sont assez rapprochés des voies respiratoires pour permettre les échanges gazeux de sorte que la vie extrautérine devient possible. Une substance ressemblant au surfactant apparaît dans l'épithélium des voies respiratoires entre la 22ième et la 24ième semaine mais n'apparait sur la surface alvéolaire que de la 26ième à la 28 ième semaine. Des stéroïdes administrés à la mère accélèrent le développement des cellules épithéliales qui recouvrent l'alvéole et la production de surfactant. La respiration foetale est initiée par le stress (ordinairement l'hypoxie). A ce moment, le liquide amniotique peut être aspiré au poumon comme l'illustre l'aspiration de méconium par le nouveau-né. ${ }^{6,7}$

Le nouveau-né normal commence à respirer spontanément en 30 ou 60 secondes. Les stimuli peuvent être le rebond thoracique après l'extraction vaginale, l'hypoxie légère ou modérée, le clampage du cordon, la fraicheur de l'air ambiant et la stimulation tactile (noter que seule une stimulation douce est nécessaire). La fessée, les bains chauds.et froids et toute autre forme de stimulation excessive n'ont aucune valeur thérapeutique et sont même nuisibles. Le volume de la première inspiration est de 20 à $70 \mathrm{ml}$ et les volumes subséquents de 15 à $20 \mathrm{ml}$. Une fois la respiration rythmique établie et les poumons complètement dilatés, la fréquence respiratoire normale s'établit à 30 à $40 \mathrm{r} \cdot \mathrm{min}^{-1}$. Dans les premières heures,
TABLEAU I Tension artérielle normale du nouveau-né

\begin{tabular}{lcccc}
\hline $\begin{array}{l}\text { Poids }(\mathrm{kg}) \\
\text { Tension mmHg }\end{array}$ & $<1,0$ & $1,0-2,0$ & $2,0-3,0$ & $>3,0$ \\
- Systolique & $40-60$ & $50-65$ & $50-70$ & $50-80$ \\
- Diastolique & $15-35$ & $20-40$ & $25-40$ & $30-50$ \\
\hline
\end{tabular}

pendant la resorption du liquide pulmonaire résiduel, la fréquence peut atteindre 60 à $90 \mathrm{r} \cdot \mathrm{min}^{-1}$. La cyanose centrale disparaît normalement cinq minutes après la naissance. Une cyanose périphérique par vasoconstriction peut persister. Pendant la délivrance vaginale, le thorax du bébé est comprimé par des pressions de 30 à 250 $\mathrm{cm} \mathrm{H}_{2} \mathrm{O} .{ }^{8}$ Cette étreinte exprime une grande quantité de liquide pulmonaire, mais le poumon demeurera collabé s'il n'est pas ventilé. Pour distendre le poumon contre l'affaisement provoqué par la tension alvéolaire et le recul élastique, le nouveau-né développe une pression négative de 40 à $80 \mathrm{~cm} \mathrm{H}_{2} \mathrm{O}^{8}$ Le réanimateur doit donc exercer des pressions élevées, s'il veut aider l'initiation de la ventilation mais il ne doit pas oublier la possibilité d'un pneumothorax accidentel. Le nouveau-né répondra à une forte et rapide inflation par une inspiration distincte, c'est le réflexe paradoxal de Head.

\section{Système cardiovasculaire}

La fréquence cardiaque varie de $100 \mathrm{à} 200 \mathrm{~b} \cdot \mathrm{m}^{-1}$ pendant les 30 premières minutes de vie mais se stabilise à 120 $\pm 50 \mathrm{~b} \cdot \mathrm{m}^{-1}$ par la suite. La pression artérielle varie avec le poids (Tableau I). ${ }^{11}$ Une pression systolique moindre que $50 \mathrm{mmHg}$ est anormalement basse et doit être rapidement corrigée par remplissage intravasculaire. Le volume sanguin normale varie de 85 à $100 \mathrm{ml} \cdot \mathrm{kg}^{-1}$.

\section{Thermorégulation}

Lhumain est homéotherme, i.e. qu'il augmente sa production de chaleur dans un ambiance froide pour maintenir sa température. Les poïkilothermes comme les reptiles ne peuvent augmenter leur température et prennent celle de l'air ambiant. Deux méthodes permettent d'augmenter la production calorique: la méthode physique, la contraction musculaire des enfants ou le frisson, et la méthode chimique sans frissonnement des nouveauxnés, la thermogénèse. Quand le nouveau-né subit un stress hypothermique, il augmente sa consommation d'oxygène et son activité métabolique. De grandes quantités de norépinéphrine sont libérées contrairement à l'adulte qui libère de l'épinéphrine. La norépinéphrine active une lipase du tissu adipeux qui dégrade la graisse brune (appelée ainsi à cause de sa riche vascularisation) pour former des triglycérides et des acides gras libres (AGL). Les AGL peuvent sortir de la cellule, peuvent être oxydés 
en dioxyde de carbone et en eau dans la cellule par réaction exothermique ou être ré-estérifiés avec du glycérol pour former des triglycérides. Le tissu adipeux est incapable de phosphoryler le glycérol dérivé des triglycérides; par conséquent, la ré-estérification par le complexe co-enzymatique A-AGL nécessite une apport de phosphate de glycérol qui provient du glucose extracellulaire. La resynthèse des triglycérides est aussi une réaction exothermique utilisant de l'ATP pour la formation du complexe co-enzymatique A-AGL.

La thermogénèse sans frissons survient surtout dans la graisse brune du nouveau-né qu'on trouve aux endroits suivants: la masse interscapulaire ou glande dhibernation, les muscles et vaisseaux sanguins qui pénètrent le détroit thoracique et les viscères, surtout les reins et les surrénales. Le drainage veineux du tissu adipeux interscapulaire rejoint celui des muscles dorsaux pour former le plexus vertébral externe. Ce dernier irrigue le riche plexus veineux péri-médullaire qui a son tour pénètre dans les veines jugulaires et azygos, fournissant ainsi la chaleur à la moelle et au coeur.

Il faut garder une ambiance thermique neutre $\left(32-34^{\circ} \mathrm{C}\right)$ où le métabolisme (i.e. la consommation d'oxygène) est au minimum tout en étant suffisant pour maintenir la température corporelle. La consommation d'oxygène demeure à son plus bas quand le gradient entre la peau et l'environnement est de $1,5^{\circ} \mathrm{C}$ ou moins. L'enfant, né dans une salle d'accouchement froide, perd une quantité énorme de chaleur par évaporation car il ruisselle de liquide amniotique et possède une grande surface d'évaporation. Quand la peau est asséchée, la perte de chaleur par radiation continue. Dham et James ${ }^{12}$ ont étudié la perte de chaleur des trente premières minutes et ont trouvé que les enfants humides exposés à l'air ambiant perdent cinq fois plus de chaleur que ceux qui sont séchés et réchauffés. Pour l'enfant vigoureux, l'assèchement rapide de l'enveloppement chaud sont presque aussi efficaces qu'une source de chaleur radiante. Cependant, chez l'enfant affaibli ou prématuré dont les réserves d'énergie sont diminuées, une source de chaleur radiante en surplomb conserve la température et permet l'accès au patient.

\section{Soins usuels du nouveau-né normal en salle d'accouchement}

Les mesures suivantes sont les seules nécessaires dans 85 à $95 \%$ des naissances (pour les autres, des mesures additionnelles s"imposent)

1 L'aspiration de la bouche et du nez avec une poire de caoutchouc.

2 L'asséchement de la peau et le maintien de la température.

3 Les mesures d'identification.
4 La prophylaxie ophtalmique (requise légalement dans la plupart des états américains).

\section{Principes de la réanimation néonatale}

Ils sont les mêmes que pour l'adulte:

1 Maintien des voies respiratoires

2 Respiration

3 Circulation

Dès la sortie de la tête, l'oropharynx est aspiré avec une poire de caoutchouc avant la première respiration alors que le thorax est encore comprimé dans le canal vaginal pour prévenir l'aspiration par la trachée de mucus et de débris. Le bébé est par la suite accouché, le cordon ombilical clampé et sectionné. Le nouveau-né est placé en Trendélembourg à 20 ou $30^{\circ}$ dans une bassinette chauffée pour faciliter le drainage par gravité. Un léger décubitus latéral facilite l'accumulation des sécrétions du même côté de l'oropharynx. Elles sont aspirées doucement avec une poire de caoutchouc; eviter si possible le cathéter de plastique ou de caoutchouc. Cordero et Hon ont étudié l'effet de la stimulation nasopharyngée ou oropharyngée sur la fréquence cardiaque. ${ }^{13}$ Chez 41 enfants qui ont été suctionnés par le nasopharynx avec une poire d'irrigation, les fréquences cardiaque et respiratoire sont demeurées stables. Par contre, sur 46 nouveau-nés suctionnés à l'aveugle par cathéter dans le nez ou la bouche, sept ont présenté des arythmies grave et cinq de l'apnée. Ces réponses défavorables sont provoquées par la stimulation vagale chez des enfants déjà très vagotoniques.

De petites tapes sur les pieds sont les seules stimulations requises pour le nouveau-né en bonne santé. Les giffles, les douches froides, les flexions en couteau de poche, la dilatation du sphincter anal, les bains chauds et froids alternants, les lits berçants et le frottement excessif du dos sont à condamner parce quinutiles et même nuisibles.

\section{Matériel requis}

Tout ce qui suit doit être immédiatement disponible:

1 De l'oxygène à $100 \%$

2 Un ballon-masque pour ventiler. Comme la plupart des nouveaux-nés n'on pas besoin de ventilation mais uniquement d'oxygénothérapie, on n'a pas à administrer nécessairement l'oxygène sous pression positive. $\mathrm{Ce}$ pendant si la ventilation artificielle devient nécessaire, on doit être capable d'administrer l'oxygène avec un masque facial coussiné sous ventilation manuelle.

3 Une poire de caoutchouc pour l'aspiration du nez et de la bouche.

4 Un cathéter de deLee pour l'aspiration du mucus, du méconium, du sang et autres sécrétions.

5 Des laryngoscopes et lames 0 et 1 droites.

6 Des tubes endotrachéaux (des tubes de Cole ou des 
TABLEAU II Score d'Apgar

\begin{tabular}{lllll}
\hline Evaluation & Paramètre & Evaluation & 0 & $I$ \\
\hline $\begin{array}{l}\text { Apparance } \\
\text { Pouls }\end{array}$ & $\begin{array}{l}\text { Couleur } \\
\text { Fréquence }\end{array}$ & $\begin{array}{l}\text { Visuelle } \\
\text { Compter le pouls du cordon ou } \\
\text { ausculter }\end{array}$ & $\begin{array}{l}\text { Cyanosée } \\
\text { Absent }\end{array}$ & $\begin{array}{l}\text { Rose, extrémités bleues } \\
<100 \mathrm{~b} \cdot \mathrm{min}^{-1}\end{array}$ \\
$\begin{array}{l}\text { Grimace } \\
\text { Activité } \\
\text { Respiration }\end{array}$ & $\begin{array}{l}\text { Imitabilité réflexe } \\
\text { Taper légère sur la plante des pieds } \\
\text { Effort respiratoire }\end{array}$ & $\begin{array}{l}\text { Manipuler les extrémités } \\
\text { Visuelle }\end{array}$ & $\begin{array}{l}\text { Pas de réponse } \\
\text { Flasque } \\
\text { Absente }\end{array}$ & $\begin{array}{l}\text { Quelques mouvements } \\
\text { Légére flexion des extrémités } \\
\text { Lente, irrégulière } \\
\text { hypoventilation }\end{array}$ \\
\hline
\end{tabular}

tubes droits avec stylets en place de calibre $1,5 \mathrm{~mm}$, $2,0 \mathrm{~mm}, 2,5 \mathrm{~mm}, 3,0 \mathrm{~mm}$ et $3,5 \mathrm{~mm}$ ). Les tubes de Cole sont plus rigides et ne requièrent pas de stylets. Si l'enfant doit être ventilé mécaniquement, le tube oral doit être échangé pour un tube nasotrachéal dès que la situation le permet.

7 Des canules oropharyngées 00 et 0 sont rarement requises mais elles doivent être disponibles.

8 Une source de chaleur radiante.

Un chariot de néonatalogie avec tableaux de posologie et de dilution doit être disponible et contenir le matériel pour l'accès vasculaire et les prises de sang, les perfusions, les médicaments. La transmission du virus du SIDA (VIH) et de l'hépatite au personnel par les sécrétions orales, trachéales er stomacales du nouveau-né sont prévenues par l'utilisation d'aspirateur à vide $(<80$ $\mathrm{cmH}_{2} \mathrm{O}$ ). Ceci élimine l'inhalation de contaminants a travers un masque ou une gaze lorsqu'on aspire un tube endotrachéal ou une suction de deLee avec la bouche.

\section{Evaluation et traitement}

\section{Le score d'Apgar}

On peut facilement distinguer le nouveau-né vigoureux et normal du nouveau-né en besoin de réanimation cardiopulmonaire immédiate. Entre les deux extrêmes, il existe plusieurs degrés de dépression. L'indice d'Apgar n'a pas été conçu pour guider le réanimateur, mais il demeure néanmoins un outil valide pour l'évaluation. Le score d'Apgar à une minute (Apgar 1952 ${ }^{14}$ ) peut diriger le choix du type d'intervention. On contrôle à la cinquième minute de vie pour vérifier le progrès accompli. Des contrôles supplémentaires à la dixième, quinzième et vingtième minute peuvent être effectués pour documenter la réaction du nouveau-né aux manoeuvres de réanimation.

Enfant vigoureux (Score 7-10).

Pas de thérapie spéciale

Dépression modérée (Score 4-6)

1 Administrer l'oxygène $100 \%$ au ballon-masque.
2 Stimuler en tapant les pieds ou en asséchant la peau avec une serviette douce ou une couverture.

3 Si la fréquence cardiaque demeure inférieure à 100 $\mathrm{b} \cdot \mathrm{min}^{-1}$ avec respiration inadéquate, commencer la pression positive intermittente au ballon-masque et continuer aussi logtemps que nécessaire.

4 Monitorer la fréquence cardiaque et l'effort respiratoire. Si ces signes se détériorent ou ne s'améliorent pas, traiter comme un nouveau-né gravement déprimé.

Dépression grave (Score 0-3)

1 Ventiler avec oxygène à $100 \%$ au ballon-masque immédiatement.

$2 \mathrm{Si}$ on n'obtient pas de réponse (accélération de la fréquence cardiaque, amélioration de l'effort respiratoire) en quelques minutes, réaliser la laryngoscopie, l'aspiration de l'oropharynx et de la trachée, et intuber pour pouvoir ventiler.

3 Débuter le massage cardiaque à thorax fermé si la fréquence demeure inférieure à $100 \cdot \mathrm{min}^{-1}$. Placer les deux pouces à la jonction du tiers moyens au tiers inférieur du sternum et les autres doigts sous le thorax. ${ }^{15,16}$ Comprimer le thorax à la fréquence de $120 \cdot \mathrm{min}^{-1}$ en déprimant le sternum aux deux tiers vers la colonne vertébrale.

4 Monitorer l'efficacité de la réanimation cardiopulmonaire. Avec l'intubation et la ventilation, le thorax doit prendre de l'expansion et la respiration perçue à l'auscultation des aisselles. Ausculter l'estomac pour éliminer l'intubation de l'oesophage. Si la ventilation et/ ou l'intubation sont difficiles, repositionner la tête. A cause de sa tête relativement plus grosse et de l'oedème accumulé à l'occiput pendant le travail, le cou peut rester suffisamment fléchi pour comprimer la trachée en décubitus dorsal. Placer un petit rouleau sous les épaules pour permettre l'extension du cou. Noter qu'avec l'hyperextension on peut aussi comprimer la trachée.

5 On ne doit pas aspirer l'estomac pendant les premières minutes de la vie pour éviter les arythmies de la stimulation naso- et oropharyngée - à moins d'une dilatation gastrique massive secondaire à la pression pos- 
itive. Cordero et Hon ${ }^{13}$ suggèrent d'attendre cinq minutes lorsque le nouveau-né est stable et tolère mieux cette manoeuvre.

\section{Dépression modérée à grave persistante}

Sil ne répond pas à la ventilation avec oxygène et au massage cardiaque fermé, le nouveau-né a besoin d'une thérapie supplémentaire.

On administre les drogues pour la réanimation par cathétérisation ombilicale artérielle ou veineuse, bien qu'à défaut d'accès vasculaire on puisse administrer l'épinéphrine par le tube endotrachéal. Une canule 5 ou 8 French peut être insérée dans l'artère ombilicale, mais souvent la vasoconstriction oblige à utiliser la veine ombilicale. Dans ce cas, le cathéter ne doit être poussé à plus de $2 \mathrm{~cm}$ dans la veine pour éviter de canuler un vaisseau hépatique.

\section{Drogues utilisées pour la réanimation}

Epinéphrine $\left(0,05 \mathrm{mg} \cdot \mathrm{kg}^{-1}\right)$

Le bébé hypotendu, bradycarde et acidotique aura besoin d'une dose aussi élevée. Pour le nouveau-né non acidotique, la dose de $0,01 \mathrm{mg} \cdot \mathrm{kg}^{-1}$ suffit.

\section{Bicarbonate de soude $\left(2 \mathrm{mmol} \cdot \mathrm{kg}^{-1}\right)$}

Selon toute probabilité, le nouveau-né asphyxié qui ne répond pas à l'oxygène et à la ventilation artificielle souffre d'acidose métabolique et respiratoire. La première dose de bicarbonate diminuera l'acidose et les doses supplémentaires ne doivent être administrées qu'après vérification du $\mathrm{pH}$. On prélève un échantillon de sang (artériel ou veineux) à linsertion du cathéter ombilical. La ventilation artificielle suffit en général pour renverser la fraction respiratoire de l'acidose. La thérapie au bicarbonate peut causer ses propres complications. ${ }^{17-20}$ Comme c'est une solution hyperosmolaire, son administration rapide peut produire une vasodilation et une hypotension profondes par vasodilation des vaisseaux musculaires squelettiques et pooling veineux. A cause de son osmolarité inférieure, la solution de $0,22 \mathrm{mmol} \cdot \mathrm{ml}^{-1}$ est préférable à la solution de $0,45 \mathrm{mmol} \cdot \mathrm{ml}^{-1}$. On devrait l'administrer en perfusion intraveineuse (dans le dextrose 5 ou $10 \%$ ou le physiologique $0,45 \%$ ) de façon à en diminuer l'effet flash. Le thérapie bicarbonatée excessive peut conduire à l'hypernatrémie impliquée dans l'hémorragie intracrânienne du nouveau-né. ${ }^{20}$ Les doses contrôlées par le $\mathrm{pH}$ de l'enfant ne présentent pas cet inconvénient majeur.

Naloxone $\left(0,1 \mathrm{mg} \cdot \mathrm{kg}^{-1}\right.$ iv ou $0,2 \mathrm{mg} \cdot \mathrm{kg}^{-1}$ im)

Le nalaxone est utilisé uniquement pour renverser la dépression induite par les morphiniques reçus par la mère. Si tel est le cas, le nouveau-né doit être sous observation pendant au moins quatre heures pour obvier à la récurrence possible de la dépression respiratoire. $\mathrm{Si}$ la mère a reçu une anesthésie générale, l'anesthésique peut avoir un effet dépresseur sur le nouveau-né. A ce moment tout ce dont le bébé a besoin, c'est de l'oxygène, de la stimulation et le temps de s'éveiller. Le nalaxone est inutile dans ce contexte, à moins que la mère n'ait été anesthésiée avec des opiacés.

Le dextrose $\left(2 \mathrm{mg} \cdot \mathrm{kg}^{-1} \dot{\nu}\right.$ en bolus et 5-8 $\mathrm{mg} \cdot \mathrm{kg}^{-1} \cdot \mathrm{min}^{-1}$ par la suite en perfusion)

Les enfants asphyxiés sont souvent hypoglycémiques. Cette hypoglycémie est provoquée par l'augmentation initiale du taux de catécholamines avec hyperglycémie secondaire. L'hypersécrétion insulinique suit en présence de réserves de glycogène déjà basses et une glyconéogénèse immature. ${ }^{5}$ Les nouveaux-nés de mères diabétiques sont encore plus à risque d'hypoglycémie par exposition prolongée à l'hypoglycémie maternelle, avec hyperplasie des cellules des ilots pancréatiques foetaux et augmentation consécutive de l'insulinémie. Les nouveaux-nés de petit poids ou ceux qui ont souffert d'insuffisance utéroplacentaire souffrent d'hypoglycémie par déplétion des réserves de glycogène. Dans ce dernier cas, l'hypoglycémie peut apparaître tardivement et nécessiter une surveillance biologique prolongée.

D'autres médicaments peuvent être requis pour une réanimation prolongée. Nous ne discuterons pas ici de leurs indications et de leur administration qui sont la responsabilité du pédiatre.

\section{Problèmes néonataux spécifiques}

\section{L'aspiration méconiale}

Le passage de méconium par le foetus est une réponse au stress hypoxique des périodes ante- et péri-partum. ${ }^{21}$ L'expulsion de méconium survient dans $8-15 \%$ des grossesses, avec une incidence plus grande pour les grossesses à terme dépassé. La plupart des nouveaux-nés accouchés dans du liquide teinté de méconium en portent dans la trachée. Si on ne les traite pas, ils peuvent développer le syndrome d'aspiration du méconium. ${ }^{22-24}$ Comme le traitement de ce syndrome n'est que symptomatique, c'est sur sa prévention qui consiste à aspirer vigoureusement le méconium dès la naissance, qu'il faut concentrer ses efforts. ${ }^{23-25}$ La présence de méconium épais dans le liquide amniotique, dicte la thérapie suivante: dès la sortie de la tête, alors que le thorax est toujours dans le vagin ou l'utérus (pour la césarienne), avant la première respiration, l'obstétricien doit aspirer l'oropharynx et le nasopharynx avec une poire en caoutchouc ou un cathéter de deLee. Immédiatement après la naissance, et si pos- 
ible, avant la première respiration, la laryngoscopie et la suction trachéale doivent être exécutées par la personne sur place la plus compétente, qu'il y ait ou non du méconium dans l'oro- ou le nasopharynx. La suction trachéale doit être répétée jusqu’à la disparition complète du méconium. Un assistant doit monitorer la fréquence cardiaque pendant cette manoeuvre, car elle peut provoquer des bradycardies et autres arythmies par stimulation vagale. ${ }^{13}$ Si la fréquence cardiaque ralentit, on doit administrer de l'oxygène au masque ou par un tube endotrachéal propre en exerçant une pression positive intermittente. Les enfants qui ont aspiré du méconium doivent subir de la physiothérapie thoracique et du drainage postural avec aspirations et doivent être surveillés de près. $\mathrm{Ce}$ régime d'aspiration immédiate et complète de l'oro- et du nasopharynx a grandement reduit l'incidence et la gravité du syndrome d'aspiration du méconium et de la morbidité et de la mortalité subséquentes. ${ }^{23,24}$

\section{Le choc néo-natal}

L'hypovolémie grave suivie d'hypoperfusion secondaire et d'hypoxie survient sous linfluence de plusieurs facteurs. La sequestration de sang dans le placenta causée par l'élévation du bébé au-dessus de la mère au moment du clampage du cordon, le prolapsus du cordon, le décollement prématuré du placenta, le placenta praevia et la rupture du cordon peuvent diminuer de façon importante le volume sanguin du nouveau-né. Les bébés de petit poids ont souvent une diminution des protéines totales avec une fuite de liquide intravasculaire par baisse de la pression oncontique. Le sepsis maternel peut aussi se transmettre au foetus pour produire un choc néonatal.

La chute de la tension artérielle, la tachycardie, la paleur, un débit urinaire diminué, la baisse de l'hématocrite ou l'acidose métabolique sont tous des indication de remplissage vasculaire. Une thérapie, difficile d'application, consiste à injecter $20 \mathrm{ml} \cdot \mathrm{kg}^{-1}$ de sang foetal placentaire complet hépariné non contaminé. ${ }^{26,27} \mathrm{Si}$ ce n'est pas possible, on utilise du sang frais complet d'adulte ou dans la plupart des hôpitaux, du culot globulaire et du plasma frais congelé. L'albumine $5 \% 1 \mathrm{~g} \cdot \mathrm{kg}^{-1}$ sert aussi à cette fin. Finalement, à défaut de sang, on administre une solution de lactate de Ringer ou de physiologique $0,45 \%$. La tension artérielle, le pouls, la respiration et la température sont monitorés avec soin pour déceler tout changement avant quil ne devienne catastrophique.

Le monitorage continu du nouveau-né hypotendu est essentiel. La mesure de la tension artérielle fait partie de l'évaluation physiologique essentielle à la naissance. Le nouveau-né récupère de l'asphyxie de la naissance et doit profiter de la même surveillance que le patient qui récupère de l'anesthésie et de la chirurgie.
Références

(Voir page R55) 